\title{
Delivering Countywide Cost-Effective and Better Education Services: The Models of Public Private Partnership (PPP)
}

\author{
Md. Mahmudul Alam* \\ Postgraduate Student \\ Institute for Environment and Development (LESTARI) \\ National University of Malaysia (UKM), Malaysia \\ Email: rony000@gmail.com
}

\begin{abstract}
Md. Abu Rashed
Sr. Consultant, Project Development

Infrastructure Investment Facilitation Center (IIFC)

An enterprise of Economic Relations Division (ERD),

Ministry of Finance, Government of Bangladesh

E-mail: arashed@infra-bd.com
\end{abstract}

\section{Citation Reference:}

Alam, M.M., and Rashed, M.A. 2010. Delivering Countywide Cost-Effective and Better Education Services: The Models of Public Private Partnership (PPP), Technics Technologies Education Management, Vol. 5(4), pp. 875- 880. Available at $<$ http://www.ttem-bih.org/pdf/ttem 54 web.pdf $>$.

This is a pre-publication copy.

The published article is copyrighted by the publisher of the journal.

\footnotetext{
* Corresponding Author

**The views expressed in the research paper are authors' own and do not reflect those of the organizations in which they work.
} 


\title{
Delivering Countywide Cost-Effective and Better Education Services: The Models of Public Private Partnership (PPP)
}

\begin{abstract}
Like other social services, education is one of the essential services that government is obliged to arrange for its country people, but to meet such increasing demand of educational infrastructures, government alone faces hues difficulties in capital investment especially in the developing countries. So, for developing the education infrastructure and providing quality education programmes, Public Private Partnership (PPP) has been proven an advanced tool for government in many of the countries. However, private investors may not have much interest for a typical PPP deal in education sector, because government provides the education services for free at the primary and secondary level. Therefore to make the PPP deal attractive to private investors, this paper suggests two approaches of PPP funding under the Built Operate and Transfer (BOT) models. Both the Viability Gap Funding (VGF) and Annuity Payment provide the investors the required subsidy from the government through payment in the construction or operation phase to make the project viable. This allows private investors to make revenue at expected level and government to save of hues up-front investments. Moreover, among different types of PPP models, the suggested types - BOT also ensures the quality of education programmes.
\end{abstract}

Key Words: Education infrastructure, PPP models, BT, BOT, BLT, VGF, Annuity Payment

\subsection{Introduction}

Social services are essential to maintain a minimum quality of life. The provision of social services is one of the primary roles of the government. It is imperative that government provides such basic services as efficiently as possible with a wide reach of effective coverage. However, the governments of developing countries are usually constrained by lack of adequate resources and over population.

Among different types of social services, education is one of the most important services. Education is also considered as one of the main agendas of development. Government always shows strong commitments towards improving the provision of the services in this sector through increasing the resource allocation. If government works alone to provide better education service to mass level, it requires more finance and longer time. On the other hand, as providing education facility is the responsibility of the government, government cannot leave it to private sector, especially in developing countries.

Under this situation, government in many countries has been adopting innovative approaches to ensure efficiency in this service. One of the approaches is liberalization of an economy with greater private sector involvement through public private partnership (PPP). PPP model has been used in UK, Northern Ireland, Japan, and Republic of Korea for developing social infrastructure, which do not generate direct revenues, such as schools, government offices, community facilities, and hospital buildings.

Education represents around 3\% of the value of PPP taken in UK. By the end of 2003, 102 educations PPP deals have been signed which value is US\$3.621 billion (UNESCAP, 2008). In 1997, USA spent USD $\$ 35.5$ billion on new school construction, of which $\$ 8.4$ billion (24 
percent) was spent on private schools - the fastest growing component of total school construction spending (U.S. Bureau of the Census, 1998). Moreover, in older cities and communities, the major school construction issue is the repair and renovation. For an example, in early 1999, New York City's Board of Education estimated it would need to spend \$11 billion for school construction over the next 5 years. (Steinberg, 1999)

In 1997, one of the province- Nova Scotia- in Canada implemented programs under PPPs to facilitate the construction of new schools. 41 new schools had been completed or approved for construction under PPP and another 12 have been proposed for approval by the end of 1998 (P W Financing 1997, 1998)

As of late November 1998, in Scotland, more than 70 schools with approximately 50,000 students in eight local authorities were scheduled to be replaced or renovated under Private Finance Initiative (PFI). The cost of this renovation and replacement initiative is expected to total USD \$554 million provided by private-sector investors (The Scottish Office, 1998)

PPP in the education sectors have been used extensively in developed countries, but very limited in developing countries. In January 2008, The Asian Development Bank noted that education in India was lagging behind its rapid economic growth with only 12,000 training and vocational institutes, compared to half a million in China. There government invites private sector to come forward to provide tertiary educations, but the outcome is not significant enough. The experts emphasized that only private investment in education cannot able to solve the problem; a PPP necessary in education to combine the agility of the private sector with the social responsibility obligation of the public sector (Kewalramani, 2008).

Individually both private and public sector has strong limitation to provide education services; only combined effort can ensure it in efficient and quick manner. The concept of PPP is relatively new which has not yet developed and established properly. Few developed countries are currently practicing PPP for service sectors, whereas developing countries as a whole are not able to provide different social services properly and also not familiar with PPP. This paper is an attempt to show a methodological approach how PPP can work as an efficient tool for the provision of education service to the public, especially in the developing countries.

\subsection{PPP Modality in Education Sector}

PPP describes a government service or private business venture which is funded and operated through a partnership of government and one or more private sector companies. In some types of PPP, the government uses tax revenue to provide capital for investment, with operations run jointly with the private sector or under contract. In other types (notably the private finance initiative), capital investment is made by the private sector on the strength of a contract with government to provide agreed services. In short, PPP can be of natures where in some instances, the capital investment is made by the government, and private player operates it, and in some other cases (in fact most of the cases) private investor solely invests and operates the venture. However there might have number of other variations in terms of level of involvement between government and the private sector in a PPP deal.

According to Canadian Council for Public-Private Partnership (CCPPP) PPP is "a cooperative venture between public and private sectors, built on the expertise of each partner, that best meets clearly define public needs through the appropriate allocation of resources, risk and rewards." The term Public Private Partnership (PPP) is not defined as community 
level but, in general, it refers to forms of cooperation between public authorities and the world of business which aim to ensure the funding, construction, renovation, management and maintenance of an infrastructure of the provision of service (The European Commission, 2004).

PPP has become a recently popular means of project implementation, especially in areas where project implementation has been unsatisfactory. PPP has the following advantages in the provision of services:

- Savings of public resources through private sector arrangement of the resources to build and finance projects

- Private sector bear both the fiduciary and safety related risks related to the construction and in some cases the performance

- Government and the public pay for the services provided by the private sector

- By Exercising the regulator power government can decide the charges, quality benchmark and curriculum

The education sector is among many of the social sectors that have benefited from the PPP initiatives of developed countries. The usual practices in the education sector in PPP projects have been the Build-Operate-Transfer (BOT) model. This model entails the private sector through open tender winning the right to build social and educational infrastructure with predesigned parameters and then operating these projects in exchange for payment or fees by the government. Even in cases where the education infrastructure exists, the government can engage a private enterprise, usually though open tender, to operate the public assets. This partnership has the advantage of combining the efficiency of the private sector and the ownership of assets as well as the regulatory authority of the public sector.

Moreover, apart from BOT, PPP in education is also applicable through Build and Transfer (BT) and Build-Lease-Transfer (BLT) model. Under BT model, investors undertake to finance and construct the infrastructure of the school or college, and after the completion of the construction the investor is required to transfer the school or the entity to the Governmental authority. The Investor is paid in a fixed amortization schedule specified in the contract document.

In a BLT model, the selected investor undertakes to finance and construct the infrastructure and leases out to the government and government provides lease rental to the investor for specified period. Generally in this model, the operation and maintenance of the project lies to the private sector and the lease rental to the investor covers this operation and maintenance cost and fees. The project is transferred to the government authority after finish the tenure of leasing period.

In the model of both BT and BLT system, private sector engages only for construction of the facility, where in BOT approach private sector also engages for construction and operation so that there is a chance to improve services delivery. In BT and BLT, the government pays for the construction only but operation belongs to the government. But under BOT model, the operation of the service that is delivering the education program belongs to the private sector for improved efficiency. Under BOT model, government subsidizes for both the construction and operation phase of the education program. But still saves a lot of money as there is no single point expenditure and save time as typically it takes long time if government builds the infrastructures and continues to operate the program by its own fund. The essential advantage 
of BOT model is that it allows the government to provide quality education programs through involving private sector.

Typically under a PPP project the investors receive payment from the users of the service through toll, fees, service charge or other relevant methods. But, in regard to the above three PPP models in education service, it is not profitable or most of the cases not possible due to government policy to impose fees on the students. The general tendency of schooling is low in developing countries, where government provides huge subsidy including books, stationeries, dress, food, cash and other incentive to attract people to send their child in school, because increasing the literacy rate is one of the most crucial development issues for the country, and education is a core obligation of government to the people. So, here government pays the investors for PPP in education sector.

In case of PPP, government outsources the construction of the facility as well as management of the entity, but controls the quality of services and the curriculum for the students. It has been experienced that such PPP models in education sector releases a lot of pressure of the government to construct numbers of educational institution through the government's own budget at a single point of time.

\subsection{PPP Model for Service Delivery and Operation}

For delivering the quality education service through PPP under the proposed system - BOT, government needs to deliver subsidy efficiently. This paper proposes two models - Viability Gap funding (VGF) and Annuity Payment - to repay the cost of construction and operation.

VGF furnishes a certain portion of the total fund requirement in order to attain viability. If the project is not capable enough for full cost recovery and attaining expected profit for the investors then to make the project viable to the investors, VGF is provided. An example can be given for a toll road where the traffic flow is very low so the private investor will not have enough revenue for its investment recovery or make desired profit out of it. If through demand analysis the IRR (Internal Rate of Return) is found say 1\% (even may be negative) and the investor expects a $20 \%$ then government will provide a subsidy generally at the construction phase to shift the IRR to $20 \%$. Here, in case of school, the investors provide the required amount of yearly VGF considering its potential income sources such as shop, canteen, rental space etc and expenditure to maintain the required quality of services.

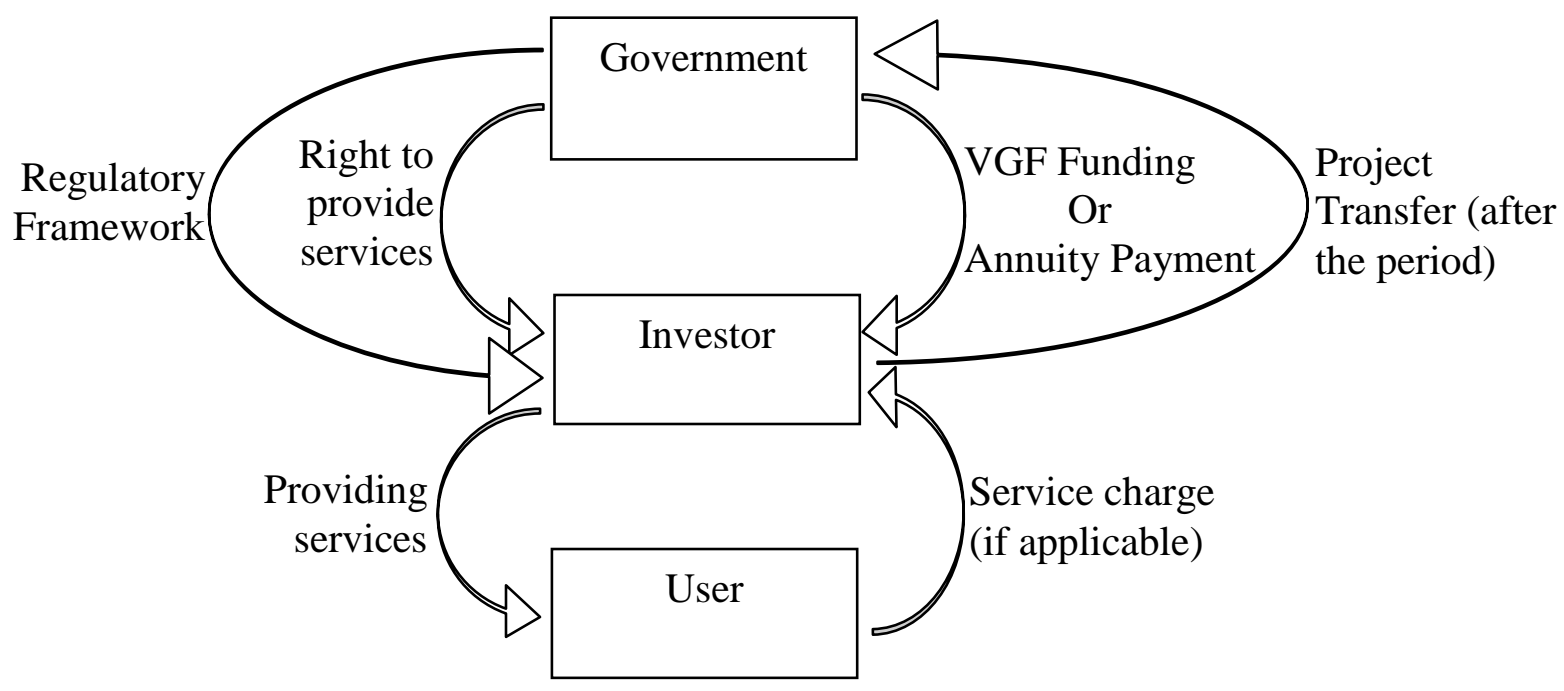


Figure 1: Model of Viability Gap Funding or Annuity Payment for PPP modality in Education Sectors

In annuity, the payment is referred for operational phases and payment is made in installments rather than the up-front as used in VGF. In many countries, payment for the IPPs (Independent Power Producers) is paid in an annuity scheme. The private investor builds the power plant and sales the electricity to the government with a premium price. The government provides confirmed annual payment to cover its costs (construction, operation and management) and revenue within the contracted period.

Generally, VGF is provided at the construction phase where the annuity payment typically provides in the operation phase. The annuity payment method has been used successfully in schools in the U.K and Australia. Generally provisions for this facility are made on a year-toyear basis. Government calls tender for selection of the investor for construction and operation for school and provides the project to the lowest quote holder

\subsection{Vital Policy Options}

PPP has also a great impact to the community based construction of schools in terms of cost savings. Under the traditional process, individual community based construction, financing, and operating arrangements, which characterizes most construction of public facilities today in many developed countries, there is always little autonomy for innovation. In many of these rapidly growing communities with a progressively increasing school-age population, classroom space and associated facilities such as, libraries, community colleges, and government offices, can be added through PPP periodically (once it is required). This saves the cost for full development of the facilities upfront. The inherent flexibility of PPPs can overcome these cost constraints by designing community specific capital project packages.

PPP, more specifically the annuity based system allows the community with the flexibility to add or deduct classroom space at minimal cost by the private sector developer through lease options with further options to renew or terminate at the end of the lease period. If, at the end of lease period, the number of student reduces, the school system can still continue with the remaining students in a smaller number of school spaces and here in such case the developer takes his sole responsibility to re-rent the unutilized space. Even, while the number of student increases, the school system could re-contract for new space as may be needed for a certain period. In both cases, the risk of holding the vacant space (if any) lies to the developers/owners, whose expertise and business skills adjusts to reuse the space more profitably.

Both VGF and annuity scheme encompasses that the government can save a lot more for the construction and service delivery as operation and maintenance through the PPP. With a certain allocation of budget for a particular year, government always enjoy the flexibility to involve private sponsors in doing the same activities for construction of more education infrastructure and on-time efficient service delivery. Instead of 100 million dollar expenditure for say 100 quality schools construction, operation and maintenance for say 10 years ,the same numbers of schools and education programmes can be introduced with 10 times lower expenditure (i.e. 10 million) with better quality in service delivery and management through the annuity scheme in PPP, where for each of the ten years the government might need to spend a bit more for the operation and maintenance but eventually government able to save almost $90 \%$ of its targeted expenditure in a particular year. Government having some priority 
expenditure issues in any particular year in an ad-hoc basis, this VGF and annuity scheme provides the best utilization. Moreover, after the term of the contract the government might receive a good running business from the private developer and operator for education sector.

PPP can shorten the time between the determination that new school facilities are needed and the completion of the project. Moreover, the management of the entity along with delivering the service is another utility of PPP in service sector, especially in education programs. In most cases, the developing countries, mobilizing funds for major public construction projects involves a complicated and lengthy process with an indecisive outcome. Delegating the financial accountability to the private developer reduces the need for the government to arrange and allocate funds for infrastructure development for education sector. This timeconsuming political and legal approval process can be greatly shortened with private-sector partnerships, although the time saved may vary from country to country and community to community depending on existing procedures and laws. With PPP, once executing agency of the government decides to go forward with the new school or colleges, they can go right to the bidding process for the selection of the private developer and operator, although instead of competing on the price to build in terms of VGF, developers may compete on the longterm lease which will be offered to the private sector for operation and maintenance.

Considering the overall impact on the business itself, the discussed PPP options are rather instrumental in designing the service delivery under education programs. This is also very important to notice that a typical construction contract is not only less justified in terms of PPP options but the assessment goes beyond the construction up to a level of satisfactory service delivery which in most cases more efficient than that of the government especially in the developing countries.

\subsection{Conclusion}

Providing social services is the responsibility of government. As government has financial and managerial limitation, ensuring these services is a time consuming process. To ensure these facilities in a quick manner, PPP can be a very good alternative. The PPP approach can provide much comfort to the government in saving large amount of money where the private investor will construct the facility, operate and maintain (BOT model) it. The government will ensure the quality of the facility such as, teacher, and curriculum, in respect of providing the VGF or annuity payment to the private investors. In addition to the substantial cost savings, PPP offer better advantages compared with current publicly financed and managed school construction methods, and delivery of education services.

To get the benefits of PPP government needs to take policy about the PPP allocation in national budget and make the legal frameworks easy and investment friendly. After that, other social services provisions such as, public health care, are also possible to incorporate in the same PPP approach.

\section{References}

Kewalramani, Sunil. 2008. Public-private Partnership in Education Needed in India. Articlesbase. October 23. Available in < http://www.articlesbase.com/college-anduniversity-articles/publicprivate-partnership-in-education-needed-in-india613627.html>

P W Financing. 1997. Nova Scotia Schools Boom. December, p. 23.

P W Financing. 1998. Nova Scotia Picks School Developers. September, p. 33. 
Steinberg, Jacques. 1999. Big Control, Little Accountability. The New York Times, January 25 , p. A24.

The Canadian Council for Public-Private Partnerships. Available at $<$ http://www.pppcouncil.ca/aboutPPP_definition.asp>

The European Commission. 2004. Public-Private Partnerships and Community Law on Public Contracts and Concessions. April.

The Scottish Office. 1998. Major Boost for Schools Buildings from Private-Public Partnerships. News Release: 2408/98, November 20, Edinburgh, Scotland.

U.S. Bureau of the Census. 1998. Value of Construction Put in Place. Current Construction Reports, C30/98-11, November.

UNESCAP. 2008. Public-Private Partnerships in Infrastructure Development, a Premier. Transport Division, Bangkok, Thailand, pp.28-29. 